pesquisa conclui pela necessária transformação da questão dos desaparecimentos em um problema de segurança pública, com a criação de programas de prevenção, de busca e de retorno.

Palavras-chaves: desaparecidos civis, segurança pública, família, gênero, geração.

\title{
Rádio comunitária, espaço público e democracia: estudos de casos na França e no Brasil
}

Sayonara de Amorim Gonçalves Leal

Curso: Doutorado em Sociologia

Data da defesa: 14 de setembro de 2007

Orientadora: $\operatorname{Prof}^{\mathrm{a}} \mathrm{Dr}^{\mathrm{a}}$ Maria Francisca Pinheiro Coelho

\section{Resumo}

Este trabalho contempla o estudo do papel das rádios associativas francesas e das rádios comunitárias brasileiras como espaços públicos que abrigam diferentes lógicas de ação e onde se manifestam discursos de caráter político, cultural e social, em vários gêneros, informativo e opinativo, em especial, este último. Tais espaços são permeados por ações comunicativas e instrumentais, nos termos defendidos por Habermas, manifestas nas tensões e aproximações entre espaço público e espaço comum.

Com base em estudos de casos dessas mídias, constata-se a dinâmica desses espaços e as lógicas de ação que operam em seu 
interior. As formas de funcionamento permitem avaliar se essas rádios se configuram em locus de debates públicos que envolvem a comunidade e favorecem o exercício de uma comunicação voltada para o interesse comum ou se elas se configuram, em grande dose, em arenas sociais de denúncias e apelos assistencialistas que resvalam para a satisfação de necessidades imediatas de membros da localidade.

Combase na aplicação de questionários, em análise documental e de programações radiofônicas e em entrevistas do tipo episódicas e semi-estruturadas, foram pesquisadas: a) 22 rádios associativas autorizadas e em funcionamento no Norte da França; e, b) 15 rádios comunitárias legalizadas na região do Distrito Federal e Entorno, no Centro-Oeste do Brasil. O estudo de caso foi aprofundado em cinco rádios de cada país.

Palavras-chave: rádio comunitária, espaço público, lógicas de ação, democracia.

\section{Música popular: janela-espelho entre o Brasil e o mundo}
Alberto Roseiro Cavalcanti

Curso: Doutorado em Sociologia

Data da defesa: 05 de outubro de 2007

Orientadora: Prof ${ }^{a}$ Dr $^{a}$ Mariza Veloso Motta Santos 